\title{
The Role of English as Lingua Franca - Informed Approach in English Language Teaching and Learning to Preserve Cultural Identity
}

\author{
${ }^{1}$ Simon Petrus Kita Ngatu; ${ }^{2}$ Basikin \\ ${ }_{1}^{1}$ Graduate School of Yogyakarta State University, Yogyakarta, Indonesia \\ ${ }^{2}$ Doctor at Yogyakarta State University, Yogyakarta, Indonesia \\ 1simon.petrus2016@student.uny.ac.id; 2basikin@gmail.com
}

\begin{tabular}{l} 
Article Info \\
\hline Article history: \\
Submitted Sept 23, 2018 \\
Revised Oct 31, 2018 \\
Accepted April 5, 2019 \\
Published April 22, 2019 \\
\hline Keywords: \\
Cultural identity, \\
English as Lingua Franca, \\
ELF-Informed Approach
\end{tabular}

\section{Article history:}

Submitted Sept 23, 2018

Revised Oct 31, 2018

Accepted April 5, 2019

Published April 22, 2019

\section{rds}

English as Lingua Franca,

\begin{abstract}
The practice of teaching English as global language that has been widely spread in Indonesia does not fit to promote Indonesian local culture. Most of English language teaching practice pays much attention to students' understanding relates to their local culture, but the whole process of English Language Teaching (ELT) itself denotes that students do not really apply their local culture in the English language learning. The effort of integrating local culture in ELT is still far from the concept of particularity, practicality, and of possibility. This article provides a conceptual perspective on the role of English as Lingua Franca (ELF) Informed Approach in ELT in terms of preserving students' cultural identity. It starts with describing the important issues dealing with the topic, evaluate the previous studies, building argument, and drawing conclusion and recommendation. The article concludes that the approach needs to be more informed in the whole process of ELT in terms of learning English and preserving students' local culture in which students are allowed to use English within their local culture rather than only in understanding their culture without practicing.
\end{abstract}

\section{Corresponding Author:}

Simon Petrus Kita Ngatu, Greaduate School of Yogyakarta Karangmalang, Yogyakarta, Indonesia.

Email: simon.petrus2016@student.uny.ac.id

\section{INTRODUCTION}

English as a global language is a fundamental property of global communication. It has become a communication medium for many people in the world. English allows people in many parts of the world to be able to communicate freely. English has been spoken globally in the different linguistic and cultural background. When English goes through global interaction, English is received as an official language.

Many previous researches on linguistic investigate the role of English as a global language. The concept of English as a global language opens the door of the world through which people interact with each other. Richards (2015: 5) argues about the fact that English has become the major language in communication. It provides for the high level of interconnectedness among nations, local economics, and culture. Moreover, Seargeant (2009: 63) contends that English plays its crucial role in communication because of the globalization demand. 
Jenkins (2006) argues that English has become a golden key. As a golden key, English plays an important role which enables people to interact in business, economic, politic, social, academic, and technology easily. Most of every pace of human life is connected with English. Added to this, other experts (Crystal, 1997; Krashen, 2003) documented that English language is recognized undoubtedly as the most important language among people. Since it is viewed as an important language, people spare their time and energy to learn English.

English as a global language implicates educational policy in several countries to include English as an obligatory subject. Non - native English teachers struggle to find appropriate strategies in order to improve students' ability to speak native - like English. Students are guided to follow native norms. Behaviorism theory, for instance, engages teachers to teach English through imitation, practice, reinforcement, drill, and habit formation (Goh \& Silver, 2004). Students will get low score if they do not follow the native - norms. In Indonesia, English has become an obligatory subject in junior and senior high school. Both English teachers and students are struggling to learn English and expecting to have native - like of English eloquently.

The issue of English as a global language has received considerable critical attention. Although English has been a unifying force for the business, economic, politic, social, academic, and technology has aided in bringing countries together as it found in the previous study, not everything has been beneficial. On one hand, having native - like English enable students to get high scores, people will get jobs easily and place someone in high prestigious status. On the other hand, unconsciously, we (Indonesian people), lost other important things which denotes who we are. We are in the circumstance of neglecting or denying our identity. The current Curriculum in Indonesia gives a space to both teachers and students to promote local identity as a local culture through learning English. Students are engaging to use native - like English to promote their local identities to those who come from other countries. It can be said that students are learning about their local culture, but they do not really practice how to maximize the use of their local culture. The problem is not about the effort of promoting the local culture itself but the way how to promote it. The practice of language test that has been performing is potential influencing the reduction of cultural identity awareness. It is viewed as anachronistic native - oriented ideology (Fang, 2017). Students are forced to speak English as eloquent as native speakers. To this point, how the local identity is to be promoted if at the same time, the subjects who promote it does not do so.

The practice of English language teaching to meet the demand of English as a global language has become a leading cause of the emerging of anxiety among the nations, especially people of Indonesia. English has imperialized many aspects of human life in all over the world. Linguistic imperialism as it is introduced by Philipson (1992), underlines that English plays crucial roles in maintaining the economic and political dominance of some social life. In greater length, the concept of politic according to Gee (2005: 2) means how social goods are thought about. Added to this, social goods embraces the group of people believe to be a source of power, status, value, or worth, possessions, verbal abilities, morality, and common sense. Those are known as our local identity varieties. So, at least, teaching native - like English, unconsciously, in one side eliminates cultural identity.

In the process of teaching English as a native - like, students are triggered to perform as native speakers. Speaking fluently is the main objective of learning English. Students are prevented to repeat phrases or words they speak. This is also a problem in which this will decrease the students' linguistic competence such as accommodation 
strategies and communication skill. Indonesian students' gestures and the way they speak English are originally their culture which denote their local culture.

Preserving local culture means preserving the identity in the globalization area. English language teaching plays its role to facilitate students to be able to communicate by using English without reducing or eliminating their local culture as their unseparated identity. In relation to that, by recognizing the gap between the use of English as global language and the effort of preserving local identity, this article attempts to theoretically justify the strengths of the application of the role of English as lingua franca - informed approach in the English language teaching and learning to preserve cultural identity. It should be started from the classroom since it is a crucial locus of English language teaching and learning.

\section{THEORY AND METHODS}

\section{English as Lingua Franca}

The use of the terminology of English as Lingua Franca (ELF) has become popular among countries. It appears after English is known and used as global language. Many linguists become aware of the effect of English as a global language in many aspects of human life, especially those whose first language is not English. Before going further to the terms of ELF, it is important to awake our understanding about what the English as a global Language is and how it is used among the countries where English is not their first language.

Seidlhofer (2011) defines English as Lingua Franca as a language that is used as a medium of communication among the speakers in which English is not their first language. They use English as a medium of communication as a choice to share ideas. They use English as an option because they come from the different linguistic background. Added to this, Mesthrie and Batt (2008) argue that English has become a lingua franca since the interlocutors are coming from the different lingua-cultural background (students come from different dialect, intonation, and their way of speaking). He explains that English as Lingua Franca is used widely in a full range of areas (domains) and in certain aims or purposes. Seidlhofer, Mesthrie, and Batt emphasizes on the area of using English, linguacultural possessed by the participants who share ideas or communicate by using English, and its purposes.

Blommaert (2010) adds that English that is used for communication within appropriate circumstances of communicative needs without adjusting to the lexical, grammatical, pragmatic, and socio - cultural norms. This implies that the speakers of other languages use English with their local perspective. They use English with their own dialect or their own lingua-cultural background. It is interested to be noticed that people speak English while English is not their first language. They struggle to make their communication be meaningful or they can get the idea within their communication. This is in line with Beebe and Giles (1984), speakers of English from other languages have reach of strategies such as establish processes of interaction by using accommodation strategy (English is adjusted and adapted to the interlocutors' situation), body language is also used as a signal of identity to make their communication be meaningful understandable. Another usual strategy is code - switching and clarifying. They use their own words, for example, to say something that they do not know in English and then they clarify it by explain the words within the context. To support this idea, Ishikawa (2016) in his study about World Englishes and English as a Lingua Franca, he concludes that ELF theories facil itate understanding about the role of English as Lingua Franca to serve its purposes. 
To more specific, Jenkins (2000) uses the term English as Lingua Franca in relation to direct pronunciation elements in communication. It may include consonant sounds and stressing. Added to this, Seidlhofer (2004) argues about other parts of English as Lingua Franca: morpho - syntactic characteristics. It embraces lists of grammatical futures which are not following the native - speakers' norms but which are considered unproblematic in communication. Another longitudinal study involving English as lingua franca that has reported that ELF facilitates the learners to learn English based on the ELF speakers' habit, enables English teacher in assessing the students' needs, and encourages English teachers to find the appropriate of teaching method and strategies dealing with the students' needs (NAGY, 2016).

\section{Cultural Identity}

The concept of culture has various meaning. It seems to be complicated since it does not give a single definition. Many scholars have their own perspective on the terminology of culture itself. In the anthropologist perspective, Kumaravadivelu (2003) differentiates the concept of culture into two paradigms. Those are general and specific definition. In the general perspective, culture is viewed as creative events such as theater, dance, music, and literature. This perspective leads us to think that culture is the product of art creativities. In the specific concept, culture is perceived as individual construct which categorized as attitudes, behavior, values, and beliefs that play its role in controlling and shaping personal or group life within a community. The concept highlights that culture as characteristic which differentiates between one person or group to others.

Another concept of culture is proposed by Mesthrie, Swann, Deumert, \& Leap (2009) who argue that culture is perceived as the way how life runs. Here, culture embraces a set of ideas and habits. These ideas and habits are shared and inherited from generation to generations. It covers knowledge, arts, morals, law, customs, and any other capabilities and habits acquired by people as a member of society. Within this concept, it is obviously understood that the concept of culture is viewed as something that is gained through the process of learning and automatically acquire during the interaction within a society. People learn about culture because the older generation tells them about the culture they possess. Meanwhile, culture is acquired because people interact with other members within a community. So, learning and interaction contributes to the construction of human beliefs and habits.

Wardhaugh (2000) proposes a more complete definition of culture. Culture is defined as an integrated pattern of human behavior, covering thoughts, communications, languages, practices, beliefs, customs, courtesies, rituals, and expected behaviors of a racial, ethnic, religious or social group. Those are known as cultural values which contribute to the personal and social construction. It rises human's sense of understanding who they are, how they live, how they interact, how they behave. Understanding their values enable them to differentiate what is known as good or bad.

One of the cultural elements according to Wardhaugh (2000) is language. It relates to using of sounds or symbols to communicate human feeling, thought, ideas or experiences. The way how people from different culture communicate using language is different. This is because they have their own habitual or cultural background. They have their own specific of body language, slang, and common phrases. So, it has become their identity which is known as their cultural identity.

Chen (2014) points that cultural identity refers to "identification with, or sense of belonging to a particular group based on various cultural categories, including nationality, 
ethnicity, race, gender, and religion. Cultural identity is constructed and maintained through the process of sharing collective knowledge such as traditions, heritage, language, aesthetics, norms and customs". Chen highlights cultural identity as what people conceptualize their life and how they perform in social interaction. Cultural identity defines them as a particular person or groups in certain social groups.

Based on the description above, it can be said that the values of local culture should be preserved. It is important to be preserved because local culture itself is the human identity in a certain community. So, preserving local culture means preserving the human identity in the globalization era.

\section{FINDINGS AND DISCUSSION}

\section{ELF - Informed Approach}

ELF - informed approach appears in response to the native - oriented approach dealing with the essence of how English teachers assess the students' competence in classroom activities. Fang $(2016,2016)$ argues that native - oriented approach does not facilitate the students in an international arena since interaction and communication among non - native speakers of English takes place in a broad situation.

ELF - informed approach in contrast struggles with how English is assessed from an ELF perspective. ELF - informed approach called ToPIC (Teaching of English Pronunciation for Intercultural Communication) appears in the post - method approach proposed by Kumaravadivelu (2003, 2006b) as it is cited in Fang (2017) which is based on the concept of practicality, particularity, and of possibility. The indicator of particularity highlights that language pedagogy must be sensitive responsive to a certain group of teacher teaching a particular group of learners to achieve a certain goal within a particular institution context embedded in a particular sociocultural milieu (Kumaravadivelu, 2003) cited in Chen (2014). So, pedagogy of particularity emphasizes the context - sensitive to the local linguistic, sociocultural, and political future of the place where teaching takes place.

The characteristic of practicality pedagogy highlights the relationship between theory and practice and the practice of classroom teaching (Kumaravadivelu, 2001). In relation to this, O'Hanlon (1993) explains about the theory / practice dichotomy: professional theories and personal theories. Professional theories are the theories that experts created. Meanwhile, personal theories relate to those which teachers developed through interpretation and implementation the professional theories within their classroom situation. So, the teachers' role is to improve practice rather than to produce knowledge. They articulate the theories into their classroom practices.

The pedagogy of possibility highlights the concept of language teaching. Language teaching is not only about teaching grammar, vocabulary, or pronunciation, but it is aimed at encouraging students to be aware of socio-political consciousness and reflect on their living situations. It is also intended to preserve their local identity (Kumaravadivelu, 2001).

\section{The Role of ELF - Informed Approach in Preserving Cultural Identity}

ELF - Informed approach tends to be a crucial role in English language teaching for people in which English is not their first language. It might facilitate English language teaching and learning to be meaningful in the terms of learning English without neglecting 
students' cultural identity. The post method approach as the basis of ELF - informed approach explains about the important of the three parameters: particularity, practicality and possibility in teaching and learning English.

Davies, Hamp - Lyon and Kemp (2003) somewhat contend that international test such as IELTS, TOEFL, and TOEIC are kinds of penalty for non - native speakers who do not follow native norms. Students are not only forced to follow the native norms in written forms, but also the way how to pronounce the words. Those who do not follow the native patterns may not pass the exam. In order to fulfill the requirements, all the stakeholders such as the English curriculum developers, ministries of education, local government, school principals, English teachers, and students are compelled to find appropriate materials and teaching methods. Practicing and drilling to follow the native norms are apparently implemented strictly. Fang (2017) contends that the goal of such kind of teaching and learning model is rather to pass the exam than achieve pragmatic purposes.

Much of the current literature on the important of local culture seems to pay particular attention to the effort of preserving the local culture by integrating local culture into English language teaching. Sukarno (2012) tried to propose his argument on the term of integrating local culture into English language teaching, but to what extent the students really use their local culture during the classroom activities is likely being questioned. In the same view, Ilma (2016) claims that it is very essential for teachers to bring Indonesian culture to be inserted in teaching material during the process of teaching and learning. Furthermore, Ilma (2016) also contended that most of the English teachers in Indonesia seems to be lazy to find texts which embedded Indonesian local culture. Furthermore, Sugirin, Sudartini, Suciati, and Nurhayati (2011) on their study of cultural integration in the English textbooks for junior high schools seem reveals the same perspective on the focus of materials as the media for teaching cultural integration. Materials are only a part of teaching and learning process. Paying too much attention to learning local culture within the materials will influence the students to only understand what their local cultures are, but students obtain lack of experience on how to express their local culture in their real life.

The previous studies are probably failed to consider the important role of the teaching strategy which pays more attention on how both teacher and students practice the use of Indonesian local culture in English language teaching. The way of integrating culture into ELT is seemly focusing on written text. Students are triggered to learn and understand their own cultural values. Students are facilitated to be able internalize the concept of local cultures. The important point is that on one hand, the students are engaged to understand local cultures and the target cultures through learning English. Students are triggered to have native - like competence and performance to expose their local culture. On the other hand, by forcing students to have native - like English, at the same time students are likely ignoring their local culture. Students need to speak in native - like norm to express their local values. The way of using or practicing local values that are embedded in the language itself seems to get very little attention. So, if the aim of integrating local culture into the English language teaching is to enable students to be aware of local culture itself, the students should feel free to use English with their local dialect. Local dialect is the part of local cultures embedded within the language itself. They cannot be separated from the language itself since they determine from where they are.

Regarding to the above phenomena, it is likely to be important to pay great attention to the practice of the English language teaching in Indonesia in the effort of preserving Indonesian local culture through the use of ELF - informed approach as it is suggested by Kumaravadivelu (2001). ELF - informed approach consists of three parameters. They are parameter of particularity, practicality, and of possibility. Those parameters should be 
internalized in the context of ELF - informed approach in teaching and learning English and its relation to the effort of preserving local cultures.

The first parameter is the parameter of particularity. It emphasizes on the sensitive responsive of certain teachers in teaching particular students within a particular context of sociocultural milieu. This parameter highlights the role of English teachers in Indonesia about how to teach English to students from particular social life with their particular cultures. Indonesian students come into the classroom with their own cultures such as dialect. In this context, teachers should be aware that it is important to preserve their students' dialect or their way of speaking (pronunciation) as their unseparated cultures. Risager (2007) claims that since cultures spread across languages and likewise languages spread across cultures, it can be concluded that the study of a language cannot be separated from culture studies and vice versa. It seems reasonable to be said that language is a symbol of a certain culture possessed by particular students. So, preserving local culture of going extinct actually preserving local language together with its parts such as dialect, gestures when someone speaks and the way they speak the language as the nature of the approach.

The role of ELF- informed approach within this context is likely facilitating students and teachers to be aware of local culture in teaching and learning English in the whole process. Fang (2017) in his study about English as lingua franca and its implication for pedagogy and assessment seems to emphasize on the language assessment regarding to the effort of maintaining the local culture. Assessment perhaps only a part of teaching and learning as a whole process. It should cover all the process of English language teaching which is starting from curriculum designing, classroom interaction, materials, and evaluation or assessment.

The second parameter is the parameter of practicality. Along with the concept of practicality, Eusafzai (2015) contends that a language teacher is an autonomous individual able to exercise professional autonomous judgment to make pedagogical decisions which are socially, culturally and politically relevant to the local context, and also has the capacity to judge the effectiveness of the practices resulting from these decisions. The English teachers do not merely depend on the professional theory, but they are encouraged to practice from their theory and theorize their practice. It is explained that teachers make pedagogical decisions which are culturally relevant to the local context. In the whole classroom process, English teachers may facilitate students to practice the use of language (English) within their local culture and local context. This point of view is likely denotes that, speaking English by using local dialect is unproblematic. Even the ELF - informed approach may enable students to explore their linguistics skills such as accommodation strategies and communication skills. Students use their local strategic of how to explain an object such as using their local gestures or dialect. The point is that they are able to communicate their intended messages and the message could be interpreted by others. So, the role of English teachers is facilitating students to be able to communicate in English with their local culture values by providing conducive classroom atmosphere, the appropriate method of teaching and learning, and appropriate assessment. In supporting this argument, Margana (2015) in his study about blending the target culture and the home culture virtually concludes that it can be done through material orientation, learning task - orientation, media - orientation, and assessment orientation. The study is likely revealing that the process of embedding the local culture as local identity should be implemented in all the classroom process.

The third parameter is the parameter of possibility. Eusafzai (2015) cites the principle aims at "social transformation" (Kumaravadivelu, 2005) by developing learners to "critically reflect on the social and historical conditions contributing to create the 
cultural forms and interested knowledge" (Kumaravadivelu, 2003, p. 544). Based on this principle, it is presumably understood that the ELF - informed approach may enable students to have the possibility of exploring their linguistics skills such as accommodation strategies and communication skills within the conducive, and appropriate of classroom atmosphere, learning materials, teaching methods, and language assessment. Students are aware of the reach of their local culture that is not only mastering it in mind, but also in practice. They may practice how to use the language and appreciate their local culture by integrating their local culture in speaking English. They are able to reflect their particular social life and contribute exploring their local culture within their communication.

The approach seems implicitly highlighting the whole process of English language teaching to support the existence of Indonesian local culture. It may start with the curriculum design which facilitates the classroom practice to have both knowledge building of local culture and the effort of practice the knowledge of local culture itself in English language teaching. Beside that, teachers play important roles in helping the students to be aware of appreciating their local culture by providing local context materials, creating sufficient and conducive environment which enable the students to practice English in their local context, and providing language assessment which pay balance attention to the basic concept of English and the practice of English within the students' context. Those aspects should meet the requirements of its particularity, practicality, and of its possibility. The point is that having English as Lingua Franca does not mean that the basic concept of English is neglected. The basic concept of English should be viewed as a vehicle to promote and preserve cultural identity.

So, as a pedagogical implication of the ELF - Informed approach, curriculum developer should consider the students, environment, teachers, cultural background, and language assessment. Beside that, teachers are also informed to be creative in selecting materials for language teaching and learning. The materials should reflect to the students' cultures. Furthermore, it is important that teachers should apply appropriate strategies to teach the materials for students. The strategies and materials used should be able to practice in a particular time, for particular students, and in a particular lingua - cultural background. The strategies and teaching method that the teachers apply should facilitate students to have a great possibility to practice their culture in language teaching and learning. This is in line with Margana (2015) that teaching and learning process embraces materials, learning tasks, learning media, and assessment. Those aspects should facilitate students to learn and practice English with their local dialect since it is unproblematic. This is important that the students learn and understand English without neglecting their local cultures.

\section{CONCLUSION}

This article provides the discussion on the importance of rising the implication of English as Lingua Franca in English language teaching in the effort of preserving local culture identity. The discussion is based on the ELF - informed approach perspective in the practice of English language teaching. It is apparently important to take into consideration of the important of English as Lingua Franca - Informed Approach through the English language teaching within the classroom practices.

The classroom practice of English as Lingua Franca may cover the whole of classroom activities from the curriculum designing, materials, classroom interaction, and assessment. It is not only in the term of English materials and classroom assessment, but it covers all the English language classroom practice. Students are well prepared during the whole practice of English language teaching. The implementation should be based on the 
particularity, practicality, and possibility parameter as it is suggested by the post-method approach (Kumaravadivelu, 2003, 2006b).

The approach is generally urgent to be applied because it does not emphasize only on the teaching of language itself but teaching English within the context. Context here is perceived as local culture where an English language teaching applied. Basing on the ELFinformed approach, English teachers and all the stakeholders are informed to highlight and implement the importance of preserving local culture as the students' identity within the process of English language teaching. Students are not taught about their culture in English language teaching, but students are facilitated to appreciate through using their local culture in the English language learning. Learning materials, classroom practice, classroom atmosphere, and language assessment should be based on the aspects of particularity, practicality, and of possibility. So, they are not only knowing or understanding about their local culture, but they really apply their local culture values as their identity in real classroom interaction. In brief, knowing local culture without practicing how to use the values of local culture might be not an effective way to preserve students' cultural identity.

It is hoped that this article will have multiple benefits for English language teachers and any related stakeholders in the practice of English language teaching in Indonesia especially in the effort of preserving Indonesian local culture. This article is a theory - based which needs further research to conduct research - based study to prove the theory.

\section{ACKNOWLEDGEMENT}

A greatest thank goes to the Yogyakarta State Universities, especially the Graduate School of Yogyakarta University for the encouragement and motivation during the process of writing the article.

\section{REFERENCES}

Blommaert, J. (2010). The sociolinguistics of globalization. Cambridge: Cambridge University Press.

Chen, H. (2014). Key Concepts in Intercultural Dialogue. Center for Intercultural Dialogue, No. 22, http://centerforinterculturaldialogue.org.

Davies, A., Hamp - Lyons, L., \& Kemp, C. (2003). Whose norms? International proficiency tests in English. World Englishes, 22(24), 571-584.

Eusafzai, H. A. K. (2015). Foreign English Language Teachers' Local Pedagogy. English Language Teaching; 8(5), 82-93. doi:10.5539/elt.v8n5p82.

Fang, F. (2015). An Investigation of Attitudes towards English Accent at a Chinese University. Doctoral Thesis, Unpublished, University of Southampton, England.

Fang, F. (2016). Mind Your Local Accent: Does Accent training resonate to Colleges Students' English Use? Englishes in Practice, 3(1), 1-28.

Fang, F. (2017). English as Lingua Franca: Implication for Pedagogy and Assessment. TEFLIN Journal, 28(1), 57 - 70. 
Ilma, R. (2016). Promoting Local Culture in ELT to Enhance Students' Character. Jurnal Didascein Bahasa, 1(2), 59 - 69.

Ishikawa, T. (2016): World Englishes and English as a Lingua Franca: conceptualizing the legitimacy of Asian people's English, Asian Englishes, Routledge, 2331 - 2548 DOI:10.1080/13488678.2016.1171672

Jenkins, J. (2000). The phonology of English as an international language. Oxford: Oxford University Press.

Kumaravadivelu, B. (2001). Toward a Post - Method Pedagogy. Tesol Quarterly, 35(4), 537-560.

Kumaravadivelu, B. (2003) Beyond Method: Macro-Strategies for Language Teaching. New York: Yale University Press.

Kumaravadivelu, B. (2006). Understanding language teaching: From method to postmethod(Ed.). Routledge.

Margana (2015). Blended Culture as a Model of English Language Teaching at Secondary School Level. Proceeding, the $62^{\text {nd }}$ TEFLIN, International Conference.

Mesthrie, R., \& Bhatt, R. M. (2008). World Englishes: The study of new linguistic varieties. Cambridge: Cambridge University Press.

NAGY, T. (2016). English as a Lingua Franca and Its Implications for Teaching English as a Foreign Language. Acta Universitatis Sapientiae, Philologica, 8(2), 155-166. DOI: $10.1515 /$ ausp-2016-0024.

Risager, K. (2007), Language and Culture Pedagogy. From a National to a transnational Paradigm, Clevedon: Multilingual Matters Ltd.

Seidlhofer, B. (2004). Research perspectives on teaching English as a lingua franca. Annual Review of Applied Linguistics, 24 (209). DOI:http://dx.doi.org/10.1017/S0267 190504000145

Sugirin, Sudartini, S., Suciati, Nurhayati, L. (2011). A Study on Cultural Integration in the English Textbooks for Junior High Schools. Litera, 10(2), 35-46, ISSN 14122596.

Sukarno (2012). Integrating Local Cultures in Teaching English as a Foreign Language for Character Building. Jurnal Pendidikan Karakter, 2(2), 202-212. 